\title{
The Sustainable Development Goals and the Financial Services Industry
}

\author{
By Peter Jones* \\ David Hillier" \\ Daphne Comfort
}

The Sustainable Development Goals (SDGs), agreed at the United Nations General Assembly in 2015, embrace an ambitious and wide-ranging set of global environmental, social and economic targets. They are chiefly designed to promote the transition to a more viable future. The United Nations called on all governments to pursue these ambitious goals but also acknowledged the important role of the business community in addressing the SDGs. The present report provides an outline of the SDGs and of the efforts being made to encourage business engagement. It also comments on the challenges the financial services industry potentially faces in attempting to contribute to the SDGs. It is suggested that leading financial services companies should be required to identify and measure their contributions to the SDGs, integrate their achievements into sustainability reporting processes and commission comprehensive external monitoring. Finally, fundamental concerns regarding the contradicting trends of sustainability and continuing economic growth are highlighted.

Keywords: Sustainable Development Goals, Business Engagement, Financial Services Industry, Economic Growth.

\section{Introduction}

The Sustainable Development Goals (SDGs), agreed at the United Nations General Assembly in September 2015, were described as 'a plan of action for people, planet and prosperity' (United Nations, 2015). These goals are ambitious and embrace a wide range of environmental, social and economic issues, including climate change, energy, water stewardship, marine conservation, biodiversity, poverty, food security, sustainable production and consumption, gender equality and economic growth. The United Nations called on all governments to develop national strategies to pursue the SDGs but also acknowledged 'the role of the diverse private sector ranging from microenterprises to cooperatives to multinationals' in addressing these goals. In reviewing future business engagement with the SDGs, PricewaterhouseCoopers (PwC) (2015) argued that when governments sign up to the SDGs 'they will look to society and business in particular for help to achieve them'. Additionally, PwC (2015) claimed that the SDGs 'will herald a major change for business' and that 'business will need to assess its impact on the SDGs and

\footnotetext{
* Professor of Management, The Business School, University of Gloucestershire, UK.

${ }^{\dagger}$ Emeritus Professor, Centre for Police Sciences, University of South Wales, UK.

${ }^{*}$ Research Administrator, The Business School, University of Gloucestershire, UK.
} 
review its strategy accordingly.' That said, the Institute for Human Rights and Business (IHRB) (2015) suggested that 'the SDGs seem to have quietly reimagined a new model of business, relapsed as an agent of development, harnessed and channelled by governments and set to work on alleviating poverty and fostering sustainable economic growth for all.' Further, the IHRB (2015) argued that 'business is not an adjunct of aid' and that 'economic activity cannot easily be directed to where the need is greatest' but rather 'it prospers when provided with the right conditions and the right opportunities'.

There is a broad consensus that the financial services industry, including commercial and investment banks and investment, insurance, accountancy, consumer finance, credit card and financial advisory services companies, has a vital role to play promoting sustainable development. However, there are concerns that the industry has been slow in taking up the challenge. In a report issued by Ernst \& Young Global Limited (2015) it is suggested that 'the challenge for today's businesses is to address sustainability in a way that meets the current and future needs of their customers, employees, communities and the environment' and argued that 'the financial services industry has a critical role to play in making this happen across both the public and private sectors.' In proposing 'a roadmap for sustainability' for financial services, Ceres (2016) suggested that 'the financial services sector has a powerful role to play in supporting the shift to a sustainable economy through its influence on capital across global markets.' Ceres (2016) also reported that a small number of financial services companies 'have begun to demonstrate their commitment to sustainability by expanding investments in clean technology, adopting policies to address environmental and social risks' but argued that 'the sector as a whole has a long way to go.' In contributing to the Sustainability's (2016) review of global trends and opportunities, suggesting that the implementation of the SDGs will be one of the dominant themes of the sustainability agenda in 2016, Stefanos Fatiou, Chief of Environment and Development Division at the United Nations Economic and Social Commission for Asia and the Pacific, argued that 'if there is one sector we should ask more from it's the finance sector.'

Such commentaries from commercial and not-for-profit consultancies seem to be mirrored in the academic literature. Day and Woodward (2009), for example, concluded that 'although the moral and business arguments should lead organisations to be accountable to stakeholders in respect of their social and environmental impacts, the level of disclosure is lamentably low.' In agreement with the above, Scholtens (2006), for example, suggested 'there appears to be much more scope for finance to promote socially and environmentally desirable activities and to discourage detrimental activities than has been acknowledged in the academic literature so far.' More recently, in their study about the financial sector's performance in social responsibility and sustainability, Weber, Diaz and Schwegler (2014) revealed that the 'financial sector performance is relatively low regarding corporate social responsibility'. Additionally, they claimed that it was 'still not clear what influences regulations, stakeholder pressure or potential financial benefits 
have on sustainability performance in the financial sector" (Weber, Diaz and Schwegler, 2014).

Despite research on sustainability and corporate responsibility currently being reported in accounting (Huang and Watson, 2015), only a few studies examine these issues in the financial services sector. That said, Decker's (2004) research into corporate social responsibility and structural change in financial services suggested that addressing corporate social responsibility 'forces firms to realign their positions within their operating environments'. Further, he argued that in the UK retail banking sector 'the impact of corporate social responsibility is increasingly manifest in the efforts to create a competitive advantage out of corporate social responsibility strategies' (Decker, 2004). Moreover, Ogrizek (2002) observed growing conviction within the financial services industry that the most successful firms of the future will be those who pro-actively balance short-term financial goals with long-term sustainable franchise building.' Looking into social responsibility reports issued by UK's twenty largest accountancy firms, Duff (2014) concludes that 'the promotion of an active corporate social responsibility discourse allows the firm to enhance its reputation.'

This commentary paper provides an outline of the SDGs and of the efforts currently being made to encourage business engagement. Additionally, it offers important insight into the challenges the financial services industry may face in attempting to contribute to the SDGs.

\section{The Sustainable Development Goals and Business Engagement}

The SDGs have been described as demonstrating 'the scale and ambition' of the United Nations '2030 Agenda for Sustainable Development', designed to 'shift the world onto a sustainable and resilient path' (United Nations, 2015). Seventeen SDGs and 169 associated targets are documented in 'a genuinely comprehensive vision of the future' in which 'little is left unaddressed'; from 'the wellbeing of every individual to the health of the planet, from infrastructure to institutions, from governance to green energy, peaceful societies to productive employment' (IHRB, 2015). The ratification of the SDGs is the latest in the line of global sustainable development initiatives. It can be traced back to the declaration designed 'to inspire and guide the peoples of the world in the preservation and enhancement of the human environment' (United Nations Environment Programme ,1972), following the United Nations Conference on the Human Environment held in Stockholm in 1971. More recently, the SDGs are seen to build on the United Nation's Millennium Development Goals (MDGs) established in 2001. The MDGs were described as having 'produced the most successful anti-poverty movement in history' (United Nations, 2015). However, other assessments of the achievements of the MDGs have been less positive. Despite acknowledging that remarkable progress has been recorder in this field, Fehling and colleagues (2013) conclude that it has been limited and uneven across countries. At the same 
time, the involvement of the business community in the MDGs was limited with PwC (2015) commenting that 'business, for the most part, didn't focus on the MDGs because they were aimed at developing countries.'

As shown in table 1, there are seventeen SDGs with each one having a number of associated targets. For instance, goal one's targets for 2030 include eradicating extreme poverty, measured as people living on $\$ 1.25$ per day; ensuring that all men and women, and particularly the poor and vulnerable, have equal rights to economic resources, access to basic services and ownership and control over land and property; and building the resilience of the poor and vulnerable to reduce their exposure to climate change related extreme events. For Goal 6, namely to ensure availability and sustainable management of water and sanitation for all, the 2030 targets include achieving universal and equitable access to safe and affordable drinking water; protecting and restoring water related ecosystems; and improving water quality by reducing pollution, eliminating dumping and minimising the release of hazardous chemicals. Targets for Goal 12, namely to ensure sustainable consumption and production patterns, include achieving the sustainable management and efficient use of natural resources by 2030; halving per capital global food waste at the retail and consumer levels; reducing food losses along production and supply chains by 2030; and designing and implementing tools to monitor sustainable development impacts for tourism that creates jobs and promotes local culture and products.

In making the case for business engagement, PwC (2015) argued that an increasing number of "companies from all sectors are having to confront and adapt to a range of disruptive forces including globalisation, increased urbanisation, intense competition for raw materials and natural resources and a revolution in technology that is challenging the business models of many sectors while forcing all companies to be more accountable to, and transparent with, all their stakeholders.' Specifically, the Global Reporting Initiative (GRI), the United Nations Global Compact and the World Business Council for Sustainable Development (WBCSD) (2015) argued that sustainable development challenges are presenting market opportunities for companies to develop innovative energy efficient technologies, to reduce greenhouse gas emissions and waste and to meet the needs of largely untapped markets for health care, education, finance and communication products and services in less developed economies. By enhancing the value of corporate sustainability, and more specifically, by integrating sustainability across the value chain, it is argued that companies can protect and create value for themselves by increasing sales, developing new markets, strengthening their brands, improving operational efficiency, enhancing employee loyalty and reducing staff turnover. It is also argued that companies that work to adopt the SDGs will improve trust amongst their stakeholders, reduce regulatory and legal risks and build resilience to future costs and regulatory and legislative requirements. 


\section{Promoting the SDGs in the Financial Services Industry}

In looking to promote the SDGs within the financial services industry, the United Nations Global Compact and KPMG International (2015) produced the 'SDG Industry Matrix' which outlines opportunities for financial services companies to 'create value for their business whist creating a more sustainable and inclusive path to economic growth, prosperity and well-being'. Four sets of opportunities are identified. Namely, the four basic categories include initiatives for increasing financial inclusion; investing in, financing and insuring renewable energy and infrastructure projects; leveraging risk expertise to influence customer behaviour; and positively influencing environmental, social and governance practices of corporate clients and investment companies. For instance, the following actions target the goal of increasing financial inclusion: facilitating secure payment for goods and services; enabling the smoothing of cash flows and consumption over time; providing financial protection; and supporting efficient allocation of capital. Further, leveraging risk expertise requires the development of innovative pricing models which incentivize more sustainable living and production' and 'sharing nonproprietary risk data, risk analysis and risk management expertise to inform public policy and practice' (UN Global Compact and KPMG International, 2015).

The Matrix addresses each of the seventeen SDGs. Particularly in addressing goal number four, namely ensuring inclusive and equitable quality education and promoting lifelong learning opportunities, a number of initiatives for enhancing shared value are identified. These opportunities include collaborating with development financial institutions and governments to invest in innovative educational projects; expanding health, life and livelihood insurance in developing markets; and increasing collaboration across the industry to explore best practices for advancing financial literacy. Examples drawn from a number of companies, among others the InterAmerican Development Bank, Credit Suisse, Barclays, and Standard Chartered, are cited to illustrate how these opportunities can be realised. For example, Credit Suisse's 'Global Education Initiative', launched in 2008, has achieved the development of partnerships with over 400 schools across 38 countries, the training of approximately 1,500 teachers across a wide range of disciplines and the establishment of a dedicated financial education programme for girls and young women.

Eight opportunities for shared value are identified for Goal thirteen which emphasises the importance of taking urgent action to tackle climate change. These opportunities include investing in and raising capital for climate risk mitigation and climate adaptation; increasing the coverage of natural catastrophe schemes; integrating climate risks into underwriting practice, investment analysis and decision making; and taking steps to measure, reduce and report climate exposure. In this case also, a number of illustrative examples are cited to demonstrate how a number of financial services companies are promoting sustainable consumption and production. For instance, it was 
reported that the Zurich Insurance Group had launched a global flood resilience programme by bringing together a number of humanitarian organisations and private sector organisations to find new ways of enhancing resilience in both the developed and the less developed world. In looking to ensure sustainable consumption and production patterns, according to goal twelve, just two opportunities for shared value are identified; namely the development of new pricing models designed to incentivise more sustainable living and of innovative products designed to reduce energy use and greenhouse gas emissions from motor vehicles.

\section{Challenges for the Financial Services Industries}

The general headline call for greater business engagement to the SDGs can be seen as an important rallying cry but it masks underlying complexities and tensions. The IHRB (2015) argues that the role of businesses in promoting global sustainable development is complex in that it assumes companies of all different sizes and all different sectors will increasingly operate according to environmental, social and human rights standards" and that 'business models will be reconfigured as necessary to ensure sustainability of products and services, sometimes at the expense of higher profits'. Additionally, it also appears to assume "that the business community, in partnership with states and civil society, will channel a greater share of resources towards meeting SDG targets, through investment as well as philanthropy' (IHRB 2015). While the financial services industry can be seen to have a vital role in moving towards a more sustainable future, the leading players within the industry evidently face a number of major challenges in making meaningful contributions to the SDGs.

The leading players within the financial services industry face challenges, for example, in determining which of the seventeen SDGs and the 169 associated targets they select and prioritise. PwC (2015) suggests that selfinterest may drive SGD selection and companies may be 'set to cherry pick the SDGs.' In addressing the former, PwC (2015) argues that in the SDG selection process, businesses will 'see their greatest impact and opportunity in areas that will help drive their own business growth.' Further, it is claimed that 'when business profits from solving social problems, when it makes profit while benefitting society and business performance simultaneously, it creates solutions that are scalable' and asks 'should we question the motives of business if their activity and ingenuity works in the benefit of society' ( $\mathrm{PwC}$, 2015). In addressing cherry picking the SDGs, it is argued that it's clear that business doesn't intend to assess its impact across all the SDGs, its plan is to look at those relevant to their business or a sub set of these. It's less about picking the easiest, most obvious or positive ones and more about picking the ones that are material to the business' (PwC, 2015).

Across the business world, large companies increasingly employ a range of internal and external stakeholder engagement processes to determine material issues; namely, to identify and prioritise the environmental, social and 
economic issues to be addressed in their sustainability strategies. However, there is a generic contradiction concerning the nature of the relationship between the interests of the company and those of external stakeholders. While the executive management team of a company is principally, and sometimes exclusively, responsible for identifying and determining sustainability goals, such goals seem more likely to reflect strategic corporate targets rather than strong commitment to sustainability per se or to the SDGs. In the Sustainability Report published by the Royal Bank of Scotland (2015), the fifteen documented material issues are dominated by financial, operational and reputational goals. Thus, while topics related to cultural and ethical conduct, customer security, remuneration and company financial health are highly prioritised, the transition to low carbon future and financial inclusion receive lower priority materiality rankings.

Secondly, financial services companies may face the dilemma whether to develop new sustainability strategies and targets specifically to meet a number of the SDGs or simply integrate their existing strategies onto the SDGs. During the past decade, the vast majority of companies within the financial services industry have been developing and refining their sustainability strategies. Hence, they are unlikely to go back to the drawing board to ensure that they meet the SDGs. In addressing the mapping of SDGs to business activity, PwC (2015) suggests that 'the tools to map SDGs to a business currently don't exist'. Additionally, despite some companies are actually developing their own methodology, the lack of consistency in their approach to engage to the SDGs is highlighted. For multinational companies, the added complexity stemming from the absence of a single approach for national governments towards the SDGs is stressed.

Specifically, if financial services companies were to identify and pursue sustainability strategies integrated into the SDGs, they would also need to measure their achievements and integrate them into their sustainability reporting process. In addressing such measurement, PwC (2015) suggests that 'the success of the SDGs has a huge reliance on data'. In this report issued by the $\mathrm{PwC}$ (2015), it is stated that 'defining which indicators are relevant, how current business metrics align to them and potentially developing additional ones, and working out how to measure success against them, will be a significant time outlay for business as well as investment across their operations.' Further, Van Wensen and colleagues (2011) define sustainability reporting as 'the provision of environmental, social and governance information within documents such as annual reports and sustainability reports'. The SDG Compass emphasises that it is important for companies to report and communicate on their progress against the SDGs continuously in order to understand and meet the needs of their stakeholders (GRI, UNGC and WBCSD, 2015). Further, in a report issued by United Nations Environment Programme (2013) the Global Reporting Initiative appears as the leading global framework for sustainability reporting. Its comprehensive scope, its commitment to continuous improvement and its consensual approach are also highlighted. Originally founded in 1997, the Global Reporting Initiative 
framework has progressively evolved from the original guidelines launched in 2000 to the current ones introduced in 2013. It should be noted that the external assurance of sustainability reports is of central importance in the latest guidelines.

While many large companies currently claim that their sustainability reports follow the latest guidelines, their approach to independent external assurance is often limited and/or confined solely to a small number of sustainability issues and targets. Failure to commission external assurance on the sustainability reporting process is currently not a problem per se as sustainability reports are themselves voluntary and accompanying assurance statements are not subject to statutory regulation. However, the lack of comprehensive independent assurance potentially undermines the credibility and integrity of the whole process. Capturing and aggregating data on a wide range of environmental, social and economic issues, across various business activities and in a variety of geographical locations and then providing access to allow external assurance is a challenging and potentially very costly venture even for large companies. Thus, the majority of the companies do not currently choose to pursue it.

If companies are to publicly demonstrate and measure their commitment and contribution to the SDGs in the future then independent monitoring of all achievements included in sustainability reports is expected to be essential. In providing guidance on effective reporting and communication, the SDG Compass simply notes that companies can make use of competent and independent external assurance as a way to enhance the credibility and quality of their reports' (GRI, UNGC and WBCSD, 2015).

\section{Discussion}

In general, it is evident that the quality of the responses of leading financial companies to the challenges outlined above is important in determining the industry's contribution to the SDGs. However, a number of more general issues merit reflection and attention. There are issues about the ways in which financial services companies implicitly define sustainability and construct their sustainability agendas. In reality, the financial services industry has made limited attempts to define sustainability or to recognise the latter as a contested concept.

Tracing back as far as the thirteenth century, the concept of sustainability recently re-emerged in the environmental literature in the 1970's (Kamara, Coff and Wyne, 2006). Since then, it has attracted increasing attention. Diesendorf (2000) argues that sustainability can be seen as 'the goal or endpoint of a process called sustainable development.' The most widely used definition of sustainable development is the one given by the World Commission on Environment and Development in 1987. According to this definition, sustainability is the 'development that meets the needs of the present without compromising the ability of future generations to meet their own 
needs' (WCED, 1987). According to Diesendorf (2000), this definition 'emphasises the long-term aspect of the concept of sustainability and introduces the ethical principle of achieving equity between present and future generations.'

That said, sustainability is a contested concept and as Aras and Crowther (2008) argue it is a controversial topic because it means different things to different people'. There are various definitions of sustainability; some of them are essentially based on ecological principles while others prioritise social and economic developments as well as environmental goals, embracing equity in meeting human needs. A distinction is often made between 'weak' and 'strong' sustainability, with the former being used to describe sustainability initiatives and programmes developed within the existing prevailing economic and social system while the latter is associated with radical changes on both the economic and social level. For example, Roper (2012) suggests that 'weak sustainability prioritises economic development, while strong sustainability subordinates economies to the natural environment and society, acknowledging ecological limits to growth'.

While the majority of the leading financial services companies publicly emphasise their commitment to sustainability, the dominant interpretation of sustainability within the industry is built around business imperatives, efficiency and cost savings rather than any social and environmental concern. Even though many of the environmental agendas in the financial services industry are designed to reduce energy, water consumption and waste emissions, they primarily serve cost reduction. Similarly, the leading financial companies' commitments to their employees, focusing on good working conditions, health and safety at work and training promote stability, security, loyalty and efficiency of the workforce. As such, prevailing interpretations of sustainability within the financial services industry could be seen as emphasising a business continuity model, providing 'an invaluable tool for exploring ways to reduce costs, manage risks, create new products, and drive fundamental internal changes in culture and structure' (Azapagic, 2003). In general, Banerjee (2008) argue that 'despite their emancipatory rhetoric, discourses of corporate citizenship, social responsibility and sustainability are defined by narrow business interests and serve to curtail the interests of external stakeholders. As such, the successful progressive adoption of the SDGs may require fundamental changes in corporate culture. However, Fernando (2003) argues 'capitalism has shown remarkable creativity and power by appropriating the languages and practices of sustainable development.'

Secondly, the merits of the concept of shared value creation, which effectively underpins the credibility of the SDG Industry Matrix for financial services companies, are disputed. The concept of shared value, emphasising the generation of economic value of high social worth (Porter and Kramer, 2011), has been used to strengthen several arguments regarding the merits associated to business activities. For instance, it has been used to explain how banks can potentially 'create financial value while addressing social and environmental 
needs at scale' (FSG 2010). In this report, under the banner 'pursuing profits in purpose', illustrative examples of investment in renewable energy as part of a 'comprehensive Environmental Policy Framework by Goldman Sachs' (FSG, 2010) are provided. A case study of how the Skandia Group pursued a policy of 'creating shared value in Sweden's financial sector' reveals that while the company's asset management team 'sought to primarily create richer lives for their customers and society in financial terms, it also selectively focused on societal needs' (FSB, 2016).

However, Crane et al. (2014) identify numerous weaknesses and shortcomings in the applications of the shared value model. They argued that the model 'ignores the tensions between social and economic goals', being 'naïve about the challenges of business compliance'. They also claim that it is mainly 'based on a shallow conception of the corporation's role in society.' In examining the first of these concerns, they suggest that 'many corporate decisions related to social and environmental problems, however creative the decision-maker may be, do not present themselves as potential win-wins, but rather manifest themselves in terms of dilemmas'. They indicate that such dilemmas are 'continuous struggles between corporations and their stakeholders over limited resources and recognition'. In justifying their assertion that creating shared value is based on a shallow reading of the corporation's role in society, they argue that the model seeks to 'rethink the purpose of the corporation without questioning the sanctity of corporate selfinterest'.

Thirdly, there are fundamental concerns about the underlying tensions between sustainability and economic growth; particularly regarding whether continuous growth is compatible with sustainable development. Some critics would suggest that continuous growth and leads to massive consumption and thus, ever increasing depletion of the earth's natural resources. As such, it is fundamentally incompatible with sustainability. Higgins (2013) argues that 'the economic growth we know today is diametrically opposed to the sustainability of our planet.' However, in outlining its agenda for the SDGs, the United Nations (2015a) argued that 'sustained, inclusive and sustainable economic growth is essential for prosperity' but failed to define the relevant term comprising sustainability and economic growth or to explicitly recognise the environmental impacts and consequences of continuing economic growth. In an arguably more humble approach, the SDG Compass argued that 'companies will discover new growth opportunities', whilst ensuring that the global economy would operate safely 'within the capacity of the planet to supply essential resources such as water, fertile soil, metals and minerals thereby sustaining the natural resources that companies depend on for production' (GRI, UN Global Compact and WBCSD, 2015). However, there is no description of potential solutions to this complex equation. In the description of the SDG Industry Matrix for Financial Services issued by UN Global Compact and KPMG International (2015), opportunities related to the SDGS are vaguely outlined for companies to improve their business and also create more viable and inclusive paths to economic prosperity. 
The concept of sustainable consumption, which Cohen (2005) describes as 'the most obdurate challenge for the sustainable development agenda' can be seen as a particularly daunting challenge for the financial services companies aiming to engage with the SDGs. Tuncer and Groezinger (2010) suggest that the financial service sector 'with its strong leverage power is one key player to enable sustainable consumption' and that banks, for example, could offer both attractive sustainable investment packages and projects aiming to sustainability improvements. They also argue that the financial sector could improve their own business by including sustainable consumption considerations into operations. While they argue that environmental and social issues should be integrated to corporate decisions for investment, they emphasise that 'in most cases tools and capacities for incorporating these issues have to be developed.'

On the other hand, in many developed economies, there exists limited evidence of consumer appetite for sustainable consumption. The European Commission (2012) highlights that 'sustainable consumption is seen by some as a reversal of progress towards greater quality of life'. It is also observed, that sustainable consumption is viewed by some as a sacrifice of contemporary needs and desires in the name of a future characterised by uncertainty. This view is supported by Reisch, Spash and Bietz (2008), who argue that although moving towards sustainable consumption is a major issue in the international policy agenda, income growth and material prosperity by means of industrialization and consumerism remain the basic target of western economies.

\section{Conclusions}

The SDGs promote an ambitious and wide-ranging global vision for a sustainable future. While the transition to such a future demands commitments from governments and society as well as universal changes in prevalent perceptions and behaviour trends, the United Nations has already address a call to all businesses to play a central role in achieving the SDGs. Here, the underlying aim is to connect business strategies to global priorities for people and the planet. The leading financial services companies are capable of contributing in the achievement of the SDGs on an international level. However, if the financial services industry attempts to promote the transition to a sustainable global future, then it would face fundamental challenges. In their attempt to address these challenges, the leading players within the industry should be adequately advised to develop a coherent, co-ordinated and proactive approach to the SDGs and to effectively communicate this approach to all their stakeholders.

Finally, fundamental concerns remain about the tensions between sustainability and continuous economic growth. In conclusion, the present report contributes to the literature on sustainability in the financial services industry, by examining the challenges the industry seems likely to face in 
adopting the United Nation's Sustainable Development Goals and locating these challenges within a wider social and economic context.

Table 1. The Sustainable Development Goals

1. End hunger, achieve food security and improved nutrition and promote sustainable agriculture

2. Ensure healthy lives and promote well-being for all at all ages

3. Ensure inclusive and equitable quality education and promote lifelong learning opportunities for all

4. Achieve gender equality and empower all women and girls

5. Ensure availability and sustainable management of water and sanitation for all

6. Ensure access to affordable, reliable, sustainable and modern energy for all

7. Promote sustained, inclusive and sustainable economic growth, full and productive employment and decent work for all

8. Build resilient infrastructure, promote inclusive and sustainable industrialization and foster innovation

9. Reduce inequality within and among countries

10. Make cities and human settlements inclusive, safe, resilient and sustainable

11. Ensure sustainable consumption and production patterns

12. Take urgent action to combat climate change and its impacts

13. Conserve and sustainably use the oceans, seas and marine resources for sustainable development

14. Protect, restore and promote sustainable use of terrestrial ecosystems, sustainably manage forests, combat desertification, and halt and reverse land degradation and halt biodiversity loss

15. Promote peaceful and inclusive societies for sustainable development, provide access to justice for all and build effective, accountable and inclusive institutions at all levels

16. Promote, just, peaceful and inclusive societies

17. Strengthen the means of implementation and revitalize the global partnership for sustainable development

(Source: United Nations, 2015)

\section{References}

Aras G and Crowther D (2008) Governance and Sustainability: An investigation into the relationship between corporate governance and corporate sustainability. Management Decision 46 (3): 433-448

Azapagic A (2003) Systems Approach to Corporate Sustainability. Transactions of the Institute of Chemical Engineers 81(b): 303-316 
Banerjee SB (2008) Corporate Social Responsibility: The Good, the Bad and the Ugly. Critical Sociology 34(1): 51-79

Ceres (2016) The Ceres Roadmap for Sustainability: Financial Services. Available at http://www.ceres.org/roadmap-assessment/sector-analyses/financial-services

Cohen M (2005) Sustainable consumption in national context: an introduction to the symposium. Sustainability: Science, Practice, \& Policy 1(1): 22-28

Crane A, Palazzo G, Spence LJ and Matten D (2014) Contesting the Value of Creating Shared Value'. California Management Review 56 (2): 130-153

Day R and Woodward T (2009) CSR Reporting and the UK Financial Sector. Journal of Applied Accounting Research 10(3): 159-175

Decker OS (2004) Corporate social responsibility and structural change in financial services. Managerial Auditing Journal 19(6): 712-728

Diesendorf M (2000) Sustainability and Sustainable Development. In Dunphy DJ, Beneveniste J, Griffiths A and Sutton P (eds.) Sustainability: The corporate challenge of the $21^{\text {st }}$ century. Sydney: Allen and Unwin.

Duff A (2014) Corporate social responsibility reporting in professional accounting firms. The British Accounting Review 48 (1): 74-86

Ernst \&Young Global Limited (2015) EMEIA Financial Services Sustainability Report 2015.Available at: http://www.ey.com/Publication/vwLUAssets/ey-foste ring-sustainability-in-financial-services/\$FILE/ey-emeia-financial-services-sustai nability-report-2014.pdf

European Commission (2012) Policies to Encourage Sustainable Consumption. Available at: http://ec.europa.eu/environment/archives/eussd/pdf/report_220820 12.pdf

Fehling M, Nelson B and Venkatapuram S (2013) Limitations of the Millennium Development Goals: A Literature Review Global Public Health 8 (10): 11091122

Fernando JL (2003) Rethinking Sustainable Development. London: SAGE Publications.

FSB (2016) Skandia Group-Case Study: Creating Shared Value in Sweden's Financial Sector. Available at: http://sharedvalue.org/sites/default/files/resource files/Skandia\%20Case\%20Study_with\%20foreword_FINAL.pdf

Global Reporting Initiative, United Nations Global Compact and World Business Council for Sustainable Development (2015) SDG Compass: The guide for business action on the SGDs. Available at: https://www.globalreporting.org/ resourcelibrary/gssb/Item\%2029\%20\%20SDG\%20Compass.pdf

Huang, XB and Watson L (2015) Corporate social responsibility research in accounting. Journal of Accounting Literature 34(1): 1-16

Higgins KL (2013) Economic growth and sustainability-are they mutually exclusive. Available at: https://www.elsevier.com/connect/economic-growth-and-sustainabi lity-are-they-mutually-exclusive

Institute for Human Rights and Business (2015) State of Play- Business and the Sustainable Development Goals: Mind the Gap - Challenges for Implementation. Available at http://www.ihrb.org/media/images/reports/state_of_play_report-busi ness_and_the_sdgs.pdf

Kamara M, Coff C and Wynne B (2006) GMO's and Sustainability. Copenhagen: Etisk Råd.

Ogrizek, M (2002) The effect of corporate social responsibility on the branding of financial services. Journal of Financial Services Marketing 6 (3): 215-228

Porter ME and Kramer MR (2011) The Big Idea: Creating Shared Value, Rethinking Capitalism. Harvard Business Review 89(1/2): 62-77. 
PricewaterhouseCoopers (2015) Making It Your Business; Engaging with the Sustainable Development Goals. Available at: https://www.pwc.com/gx/en/sus tainability/SDG/SDG\%20Research_FINAL.pdf

Royal Bank of Scotland (2015) RBS Sustainability Report 2015: How we make a difference. Available at: http://www.rbs.com/content/dam/rbs/Documents/Sustai nability/2015docs/Sustainability_Report_2015.pdf

Reisch L, Spash CL and Bietz S (2008) Sustainable Consumption and Mass Communication: A German Experiment (No. 2008-12). CSIRO Sustainable Ecosystems.

Roper J (2012) Environmental risk, sustainability discourses and public relations. Public Relations Inquiry 1 (1): 69-87

Scholtens B (2006) Finance as a Driver of Corporate Social Responsibility. Journal of Business Ethics 68 (10): 19-33

FSG (2010) Banking on Shared Value: How Banks Profit by Rethinking Their Purpose. Available at: http://sharedvalue.org/sites/default/files/resourcefiles/ FSG_Banking\%20on\%20Shared\%20Value_0.pdf

Sustainability (2016) Global Trends and Opportunities: 2016 and Beyond. Available at: http://radar.sustainability.com/annual-trends-report/

Tuncer B and Groezinger R (2010) Financing Better Life. Available at: www.scpclea runghouse.org/upload/scp_global_outlook_related.../105.pdf

United Nations Environment Programme (1972) Declaration of the United Nations Conference on the Human Environment. Available at: http://www.unep.org/do cuments.multilingual/default.asp?documentid=97\&articleid=1503

United Nations Environment Programme (2013) Frequently Asked Questions on Corporate Sustainability Reporting. Available at: https://www.globalreporting. org/resourcelibrary/GoF47Para47-FAQs.pdf

United Nations (2015a) Transforming Our World: The 2030 Agenda for Sustainable Development. Available at: https://sustainabledevelopment.un.org/content/docum ents $/ 21252030 \% 20$ Agenda\%20for\%20Sustainable\%20Development $\% 20$ web.pdf

United Nations (2015b) The Millennium Development Goals Report 2015. Available at: http://www.un.org/millenniumgoals/2015_MDG_Report/pdf/MDG\%202015 $\% 20$ rev\%20(July\%201).pdf

United Nations Global Compact and KPMG International (2015) SDG Industry Matrix; Financial Services. Available at: https://www.unglobalcompact.org/doc s/issues_doc/development/SDGMatrix_FinancialSvcs.pdf

Van Wensen K, Broer W, Klein J and Knopf J (2011) The State of Play in Sustainability Reporting in the European Union. Available at: ec.europa.eu/so $\mathrm{cial} /$ BlobServlet?docId=6727\&langId=en

Weber O, Diaz M and Schwegler R (2014) Corporate Social Responsibility of the Financial Sector- Strengths, Weakness and Impact on Sustainable Development. Sustainable Development 22 (5): 321-335

World Commission on Environment and Development (1987) Our Common Future. Available at: http://www.un-documents.net/ocf-02.htm 